Article

\title{
Restructuring the State through Economic and Trade Agreements: The Case of Investment Disputes Resolution
}

\author{
Robert G. Finbow \\ Department of Political Science, Dalhousie University, Halifax, NS B3H 4R2, Canada; E-Mail: robert.finbow@dal.ca
}

Submitted: 8 April 2016 | Accepted: 19 May 2016 | Published: 11 August 2016

\begin{abstract}
This essay will examine the emergence of transnational governance via supranational economic agreements which promote global imposition of liberalizing policies in the interests of transnational investors. The stalled multilateral World Trade Organization (WTO) process has given way to a plethora of regional and bilateral economic agreements covering a range of new issues -investment, intellectual property, services, and regulations - which trench ever more deeply on domestic decision-making. Informed by Phillip Cerny's conception of "competition states", Colin Crouch's (2000) lament about "post-democracy", Carroll and Sapinski's analysis of "global corporate elites", and David Held's depiction of "global governance complexes", the essay will examine the role of transnational corporate and institutional elites in advancing economic agreements which narrow the scope for democratic governance. These authors depict the combination of constraint and empowerment of states induced by these transnational agreements which force most liberal democracies to cut or tweak programs and regulations in economic and social fields to protect investor rights, while boosting restraints on citizens in areas like intellectual property - what Cerny (1997) calls the "paradox" of the competition state. Given the number and complexity of these transnational governance arrangements, this essay will focus on the transnational constraints of investor state arbitration and disputes settlement systems. This will be illustrated by examining the growth of investor disputes settlement claims in bilateral treaties and major European and North American economic agreements and the rise of arbitration cases which impose costs on states for violations of investor rights. The essay considers the implications of these new forms of transnational governance for democratic governments' responsive to popular demands. It concludes by suggesting the need for revisions to theories of the democratic state, which may be morphing into pluralistic plutocracy.
\end{abstract}

\section{Keywords}

disputes resolution; global governance; investment treaties; state theory

\section{Issue}

This article is part of the issue "Supranational Institutions and Governance in an Era of Uncertain Norms", edited by Russell Alan Williams (Memorial University, Canada) and Reeta Tremblay (University of Victoria, Canada).

(C) 2016 by the author; licensee Cogitatio (Lisbon, Portugal). This article is licensed under a Creative Commons Attribution 4.0 International License (CC BY).

\section{Introduction}

"[B]ilateral and regional trade agreements are now a primary means through which greater investor protections, commodification of social services, guaranteed rights of investor access to investment opportunities, privatization of public service goods, and generally the diminution of sovereign control are being realized." (Gathii, 2011, p. 421)
The goal of deepening the global economic governance system, centered on the World Trade Organization (WTO), foundered with the resistance of emerging states in the global south, as evidenced in the deadlocked Doha round negotiations, and the stalling of the Multilateral Agreement on Investment (MAI). This does not mean that transnational economic integration and governing mechanisms have reached an impasse. A series of bilateral and regional economic arrangements, driven primarily by European and American leadership, 
have emerged instead, permitting deepening of integration and liberalization across a wide range of areas like services, regulation, investment and intellectual property rights. Tienhaara notes the dominance of legal scholars on matters relating to investment treaties and disputes resolution. While this is understandable given the legal complexities of these arrangements and the jurisprudence they reflect, she urges disciplines like political science to begin analysis of the implications for state sovereignty (Tienhaara, 2011). This analysis attempts to situate these developments in the literature on global governance and state theory to bring a political science perspective to bear.

This research will analyze the impact of bilateral, regional and transnational investment treaties on state power and assess the implications for the future character of democracy and transnational governance. Canada the United States and the European Union, among other countries, are entering an increasing array of such arrangements, including North American Free Trade Agreement (NAFTA), Canada-EU Economic and Trade Agreement (CETA), Trans-Atlantic Trade and Investment Partnership (TTIP) and Trans-Pacific Partnership (TPP). There are also many bilateral trade and investment agreements with developing states in Africa, Asia and Latin American including emerging powers like India and China. This essay will focus on the constraints embodied in these bilateral, regional and multilateral investment treaties which are creating a global governance complex which shifts enforcement of investment disputes to transnational institutions.

The analysis focuses on investor rights provisions, which may constrain what governments can do on threat of monetary or trade penalty, tilting public policy away from regulatory and spending initiatives which may be popular with voters but which impinge on investor freedoms and profits. Investor rights are increasingly enforced even against sub-national jurisdictions like provinces, states or cantons in other states as international law evolves to implement the growing web of bilateral and multi-lateral investor rights measures and make arbitrations enforceable through court actions in investor friendly countries. This essay will assess whether constraints on state power produced by investment disputes provisions limit democratic responsiveness to national majorities at the behest of investors and corporations. The focus will be on treaty-generated rules favorable to investors, enforced in arbitration and dispute settlement forums.

These bilateral and regional deals constitute an expression of transnational elite power which can be termed "pluralist plutocracy". While diversified by nationality and economic sector, elite and institutional collaborations are bound together by the overarching drive for protection and promotion of wealth. Taken together these numerous deals both constrain and empower the competition state in directions desired by transnational wealth. The forces driving the measures can be considered plutocratic in promoting the interests of wealth; but also pluralistic as they represent diverse transnational coalitions with diversifying ethno-national bases, including emerging states and sectoral concerns, with energy, natural resources, pharmaceuticals, finance being prominent examples. This is led by the interests which have promoted financialization of the global economy. Cerny, Menz and Soederberg (2005, pp. 19$20)$ note that this is a loose coalition of transnational institutions, corporations, private lobbies, think tanks and "epistemic communities" whose actions have reduced the variations possible among "competition state" models in the contemporary global economy (Cerny et al., 2005). These powerful allies have a vested interest to promote liberalization including enhanced capital flows, investor rights, intellectual property protections and deregulation with teeth through disputes settlement arrangements. The result could be a weakening of democratic accountability, with states bound to transnational agreements which constrain their actions, while requiring greater restrictions on citizens in the paradox that is pluralist plutocracy.

\section{Globalization and the State}

There is a substantial debate over the implications of globalization for state sovereignty and democratic governance. Authors divide on the amount of sovereignty left to states and the degree of constraints faced by the "competition state". Held observes the impact of globalization on democratic states, notably the "unbundling of sovereignty" and the "end of exclusive state control of territory and population"; he notes the emergence of a "global governing complex", a multiplicity of agents involved in governance in globalized system, featuring a "plurality of actors, a variety of political processes, and diverse levels of coordination and operation" (Held, 2004, p. 5). Some of these are institutionalized in transnational agreements "embodying various levels of legalization, types of instruments utilized and responsiveness to stakeholders"; others are evolving via transnational connections between "public agencies like central banks", which develop "links with similar agencies in other countries and thus forming transgovernmental networks for the management of various global issues" (Held, 2010, p. 34).

Outside these formal institutional frameworks are informal cross national interactions. Most notable are those among "diverse business actors-i.e. firms, their associations and organizations such as international chambers of commerce-establishing their own transnational regulatory mechanisms to manage issues of concern". But these are countered to a degree by "nongovernmental organizations (NGOs) and transnational advocacy networks-i.e. leading actors in global civil society-playing a role in global governance at various 
stages of the global public policy-making process" (Held, 2010 , p. 34). A balance of power is not evident, however, given the greater structural resources of the interconnected corporate world which is increasingly able to evade national regulations and to act singly and in combination to shape the power of the state and determine its limits. The acceleration of economic interconnectedness driven by interests of wealth and profit remain paramount. Institutional connections and shared interests link investors and corporate entities across borders as never before.

Analysts document the growing diversification of corporate managerial sectors, still centered around American leadership but with growing interlocking connections with European states and core emerging states in the South. Their policy advocacy organizations take two key forms, "global policy groups and transnational business councils" which provide "the transnational capitalist class and its organic intellectuals strategic resources in the struggle to protect what was won in the last three decades: investor rights, trade freedoms, low corporate taxation and other key elements of neoliberal globalization" (Carroll \& Sapinski, 2010, p. 532). There is also considerable evidence of transnational interaction among elites from core universities and in key financial and business sectors across nations (Hall, 2011). These networks have played a major role in expanding beyond the free trade ambitions of the GATT and WTO towards broader conceptions of investor freedom and deregulation to open capital across international borders (Carroll \& Sapinski. 2010, p. 511).

As new tools for interaction and especially technologies for transfers of wealth and interests allows such actors, a transnational pluralistic plutocracy, to avoid state regulations or alter them to suit their preferences, these actors are in a strong position to press states to adopt permanent limitations on sovereignty or reorientation in state policies on investment, intellectual property, regulation etc. to promote their unfettered interests in global liberalization and capital mobility. These are the organizations driving integration and liberalization in a multi-faceted fashion across trade, intellectual property, regulation and investment. In the investment field, these groups reveal themselves at consultations in the US, Canada and the EU on investor-state provisions which attracted numerous corporate, business association and think tank commentaries, balanced by civil society and union input. They are also evident in core instructions like Organization for Economic Cooperation and Development (OECD), United Nations Conference on Trade and Development (UNCTAD) and World Bank which extensively study investment arbitration and publish research underlying the system's evolution. Less visibly these can be seen in the legal arbitration sector whose members may act as prominent promoters of the system (Olivet \& Eberhardt, 2012).

\section{Emergence of Investor-State Dispute Settlement (ISDS)}

One of the signature accomplishments of this transnational network has been the creation of a transnational regime for investment, which since the late 1960s has been reinforced by investor-state disputes resolution institutions. After World War II, the negotiation of the General Agreement on Tariffs and Trade (GATT) was meant to be accompanied by a parallel investment agreement, but this was blocked in the US Congress as too ambitious and restrictive (Åslund, 2013). The emergence of the bilateral investment treaty (BIT) regime was initially slow, with the first concluded between Germany in Pakistan in 1959. Some 70 more were inked in the 1960s and 93 in the 1970s. Investment exporters like the US and European states negotiated investment arrangements with developing countries, to counter Cold War threats of expropriation and nationalization by Soviet-linked regimes. These agreements extended national and most favoured nation treatment to investors, giving them freer access to investment opportunities. They also limited expropriations to those essential for public well-being, required fair and prompt compensation, and protected investors against exchange controls and limits on repatriation of profits. These agreements also innovated in including a "dispute resolution provision consenting to the jurisdiction of the International Court of Justice over disputes involving the interpretation or application of the agreement", although investors had first to work through domestic legal remedies before availing themselves of this process (Vandevelde, 2005, p. 165)

Vandevelde notes that investment treaties were unbalanced measures, usually between developed and developing states; the latter, capital importing states assumed most of the obligations to ensure protection for investors. These included bans on capital controls, local hiring or purchasing preferences and other performance requirements. They also provided for compensation for direct seizures or indirect expropriation if regulations diminished or removed the value of investments. These investor state agreements (ISAs) replaced a previous ad hoc system whereby investors had to get their home governments to seek remedies from a foreign country where they had holdings, through diplomatic or occasionally military means. In this "colonial" approach (Vandevelde, 2005), countries like the US might resort to gunboat diplomacy (as happened frequently in Latin American and Caribbean states) when host countries refused to compensate investors for expropriation or losses induced by government action, or afford them legal protections and due process.

The inclusion of binding arbitration implemented after 1965 by the World Bank's International Center for the Settlement of Investment Disputes (ICSID) estab- 
lished the framework for private party initiated arbitrations which remains in place today. The system of investor state provisions enabled investors to make claims against signatory states regularizing the system and rendering it independent of diplomatic relations between countries. This created a set of rights for investors who could work through arbitration under international law to secure compensation, without requiring diplomatic or military interventions by their host countries (Vandevelde, 2005, p. 175).

The most ambitious plan for global governance in this sector was the proposed Multilateral Agreement on Investment (MAI) which was a proposed international investment agreement as a companion to the GATTWTO system. Efforts to add investment protections to the WTO system, like previous efforts through GATT, foundered on differences between developed states keen to secure investor protections and developing countries seeking to promote domestic policy goals, so negotiations were transferred to the OECD of developed states. Its proponents portrayed it as an effort by states to limit sovereignty in the interest of enhanced economic well-being, arguing that liberalized investment would create long-run positive sum growth in the global economic space. It would protect investors from arbitrary and unreasonable actions by governments and enhance the rule of law where required. Critics responded that the MAI would empower "foreign investors to challenge the law-making authority of nation states and subnational governments" by creating "an international forum with the power to award monetary damages against the offending government". The deal was portrayed as a virtual "coup d'etat" which would impose "corporate rule" via an "economic constitution" which would transfer power to investors at the expense of governments (Stumberg, 1998, p. 493). Critics noted the potential constraints of the penalties, "shifting power in the legislative process through the economic leverage of investor remedies" (Stumberg, 1998, p. 495). Supporters countered that arbitration procedures were increasingly common across economic and other policy fields and ruled by courts to be constitutionally acceptable. The MAI negotiations were permanently paused in late 1998, reflecting divisions among proponents as well as a successful civil society campaign to block this "antidemocratic" initiative.

In the wake of the MAl setback, similar measures have been included in bilateral economic agreements between states, to allow the investors of a capital exporter to protect their investments in a situation of legal and political uncertainty. Contemporary investment treaties typically include a few core elements including standards such as "fair and equitable treatment" alongside "National treatment or Most-Favoured Nation" (Peterson, 2004, p. 3). They include guarantees against expropriation or nationalizations without compensation, freedom for capital movement, and increasingly a form of dispute-settlement process (either state-tostate or investor-to-state). Most of these agreements have been bilateral, but such provisions have also been included in multilateral economic agreements, including the major regional trade agreements involving European and North American States.

Vandevelde refers to the 1980-2000 period as a "global era" for ISDS after the end of the Cold War, when the "end of history" presumption of liberal capitalist uniformity meant developing and transitional socialist states accepted investment liberalization on American and European terms (UNCTAD, 2000). The pace of negotiation and adoption of ISDS provisions increased over time, peaking around the turn of the millennium, (Figure 1 ) though reducing in frequency more recently.

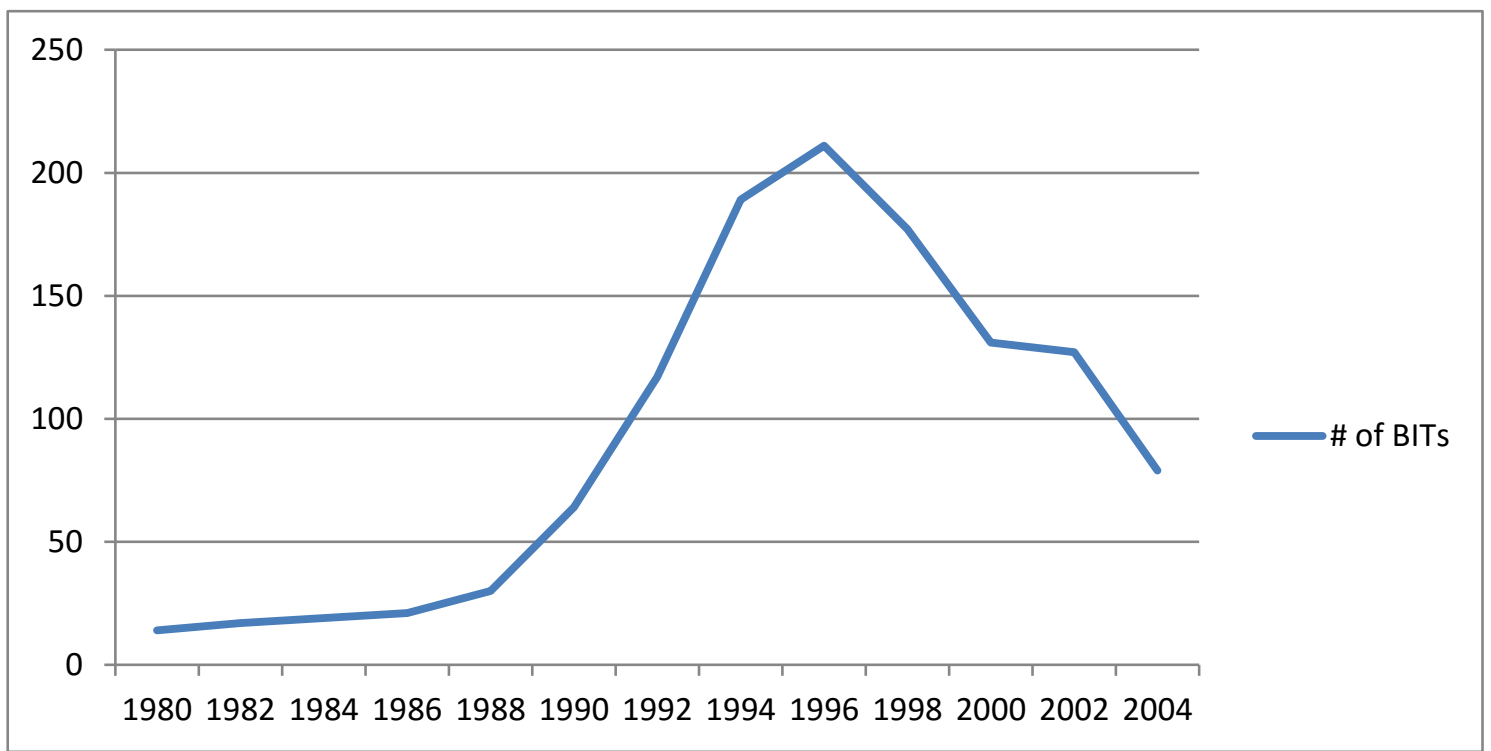

Figure 1. Number of new BITs per year. Source: UNCTAD (2006) 
Gordon and Pohl $(2015$, p. 36) note that as the pace of bilateral investment treaties slacked off, replacement agreements became more prominent. But the overall number of BITs (also accompanied by other forms of investment agreements including multinational regional deals like NAFTA and TPP) brought the total number to 2500 by 2005 (Figure 2). While the pace has slowed somewhat, there are currently around 3300 agreements (UNCTAD, 2015).

Investor state disputes resolution (ISDS) mechanisms create processes whereby states can be directly challenged by actual or potential investors over loss of real or anticipated profits. In most of these systems, ad hoc tribunals drawn from a set of legal professionals determine if a state has breached investment obligations; they can decide on damages, and impose costs and penalties with limited possibility for review and limited transparency or release of justification for decisions. The pacts can be used to impose settlements, which domestic courts may have to enforce; but in the absence of compliance by a respondent state, international law may be used under the New York or Washington Conventions on arbitration settlements to enforce judgements in an investor-friendly jurisdiction.

Kaushal argues that "Foreign direct investment ('FDI') and bilateral investment treaties ('BITs') have become key building blocks of the international legal and economic architecture.... This network of BITs has engendered a regime of investment treaty arbitration complete with dedicated international institutions" with, "common procedural rules, substantive obligations, a rotating group of arbitrators, a specialized cadre of lawyers, and a growing body of decisions" (Kaushal, 2009, pp. 491-492). Bilateral and regional investment agreements made up for the lack of enforceable investor rights in the WTO, permitting direct claims against states. Investment treaties "increasingly offer foreign investors an opportunity directly to challenge breaches of WTO law and to seek relief in the form of cessation of the WTO-inconsistent measure and, when the measure can be shown to have proximately caused them injury, damages" (Verhoosel, 2003).

\section{Investor Disputes Settlement Systems as a Contested Global Governance Complex}

Initially only a trickle of investment disputes went to arbitration processes, mostly targeted at developing states with uncertain legal protection for investors. Disputes resolution cases have increased dramatically over the last 30 years. Investor state disputes mechanisms have grown ever prevalent and are becoming a more routine means for transnational enforcement of liberalized investment rules. Many of these are conducted under the World Bank's International Centre for Settlement of Investment Disputes (ICSID) system which uses ad hoc arbitrators chosen by the parties rather than permanent professional adjudicators. Other investment treaties rely on bilateral or regional arrangements specific to the BIT in question.

The United Nations Commission on International Trade Law (UNCITRAL) sets general rules for disputes settlement which may be addressed through the ICSID institutions or the Permanent Court of Arbitration (PCA) in The Hague. Other investment treaties may permit parties to make claims via commercial arbitration centers like the Arbitration Institute of the Stockholm Chamber of Commerce (SCC), London Court of International Arbitration, or the International Chamber of Commerce's Court of International Arbitration in Paris. But as shown in Table 1, a substantial majority of the known cases take place under the World Bank ICSID umbrella.

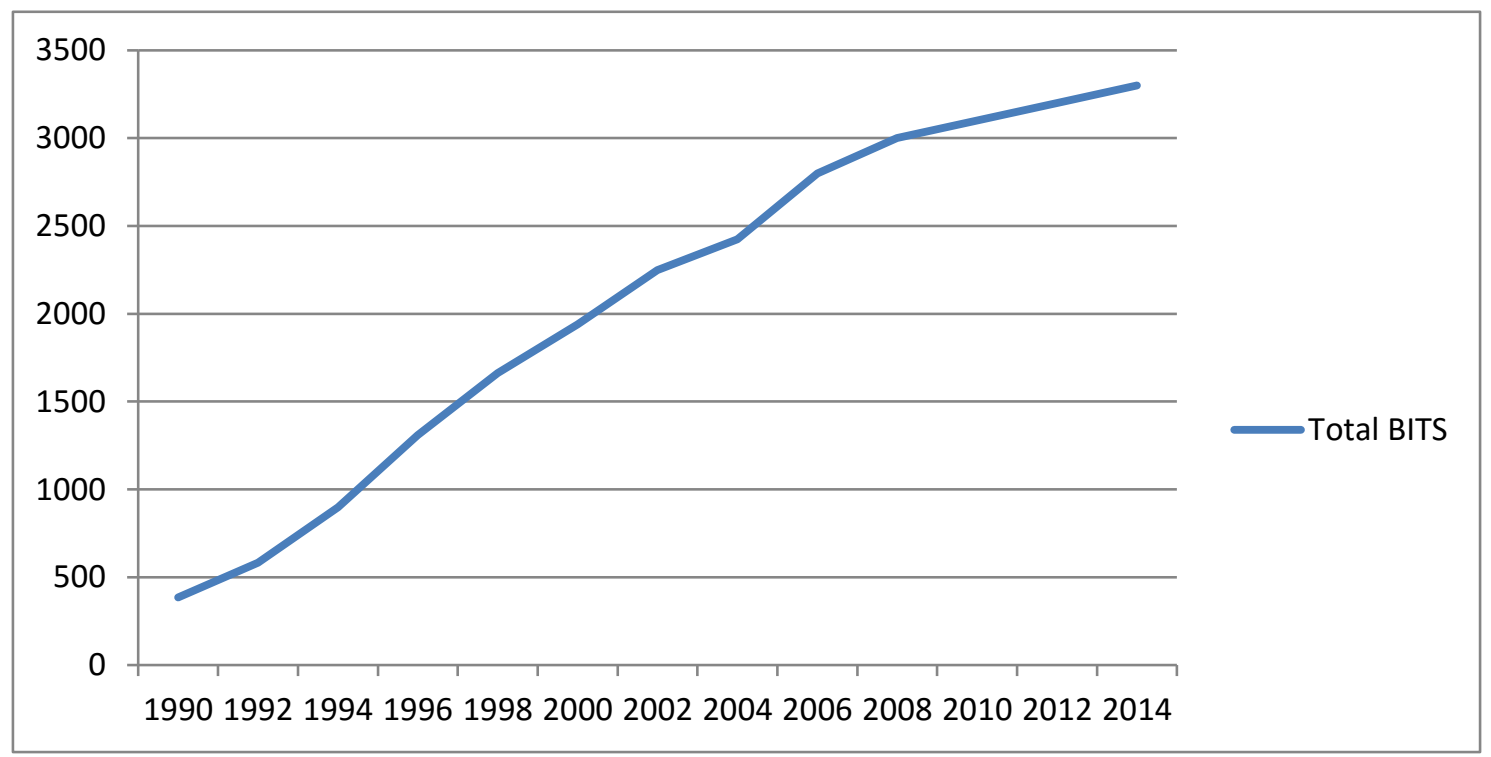

Figure 2. Total number of BITs in force. Source: UNCTAD $(2006,2015)$. 
Table 1. Major administering investment arbitration institutions. Source: http://investmentpolicyhub.unctad.org/ISDS/ FilterByRulesAndInstitution

\begin{tabular}{lll}
\hline Acronym & Institution & \# of Cases \\
\hline CRCICA & Cairo Regional Center for International Commercial Arbitration & 2 \\
ICC & International Chamber of Commerce & 4 \\
ICSID & International Centre for Settlement of Investment Disputes & 451 \\
LCIA & London Court of International Arbitration & 5 \\
MCCI & Moscow Chamber of Commerce and Industry & 3 \\
PCA & Permanent Court of Arbitration & 83 \\
SCC & Stockholm Chamber of Commerce & 35 \\
\hline
\end{tabular}

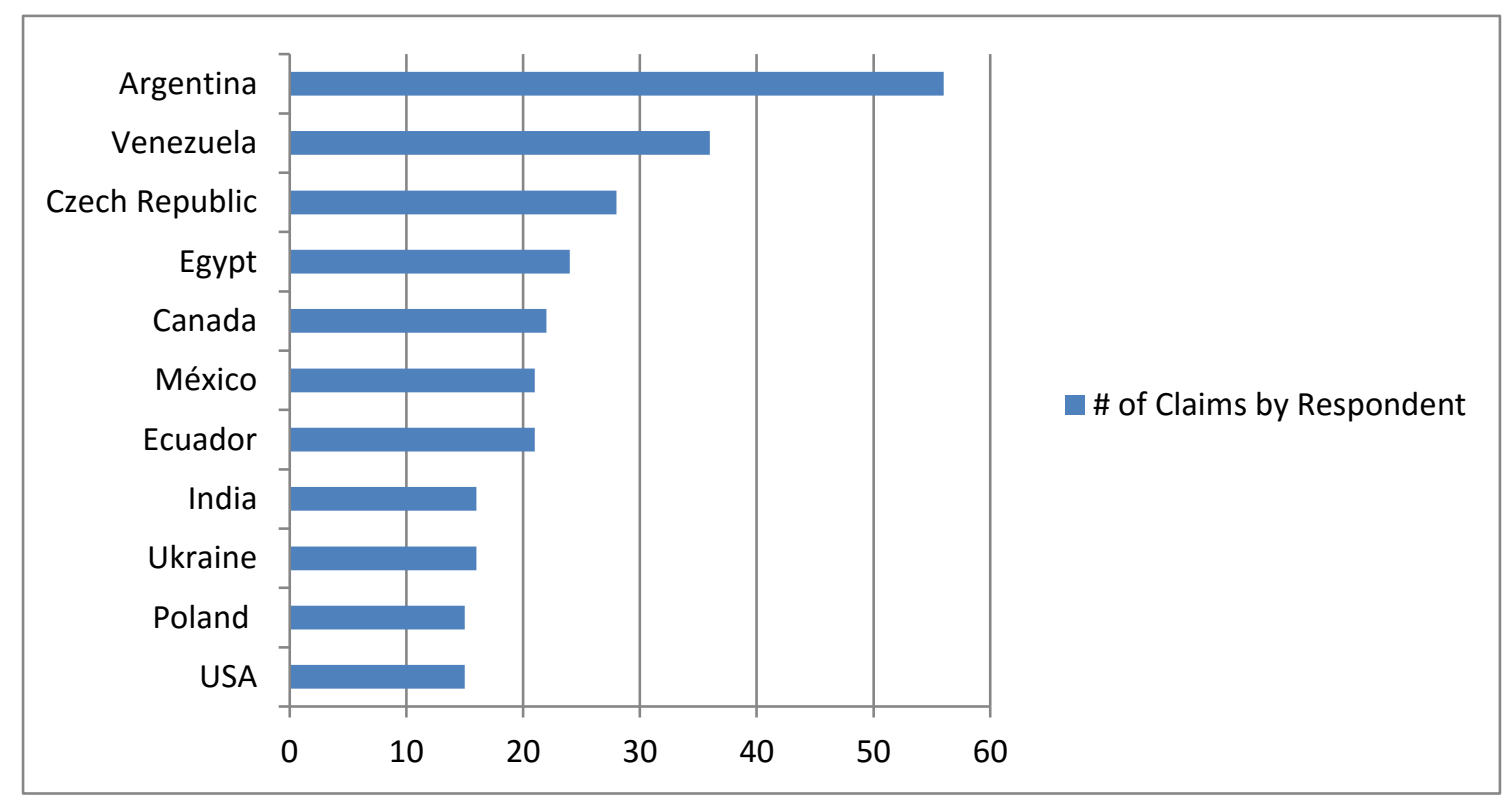

Figure 3. Number of claims by respondent state. Source: UNCTAD (2015).

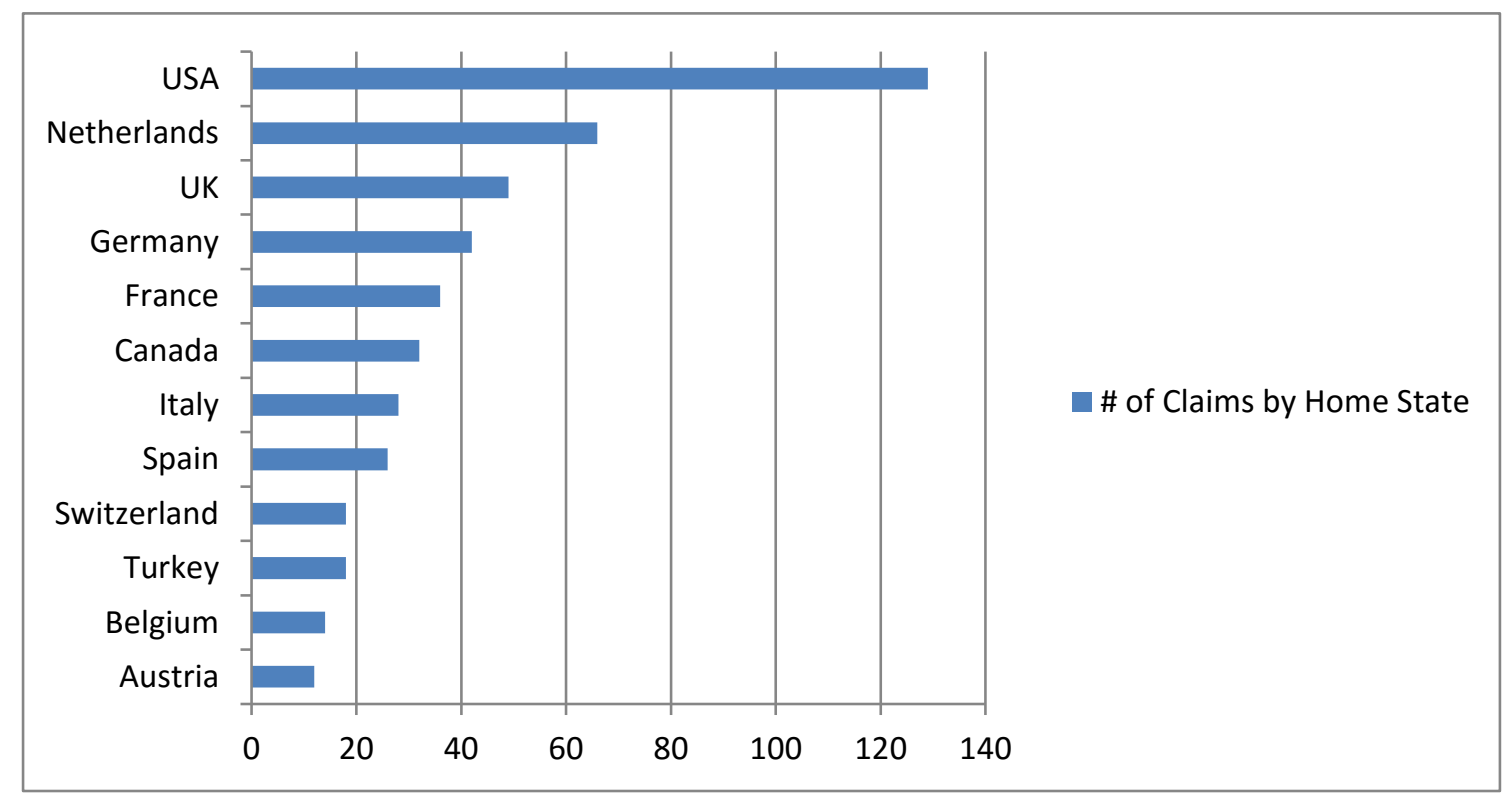

Figure 4. Number of claims by home state. Source: UNCTAD (2015).

Initiation of cases and issuance of decisions have escalated substantially. As Figure 3 shows, these mostly target developing and post-Soviet states. Increasingly these cases have targeted developed states, especially Canada, with more questions raised about the necessity given enforceable investment protections and dependable rule of law in most post-industrial states.

But as shown in Figure 4 the states making most use of these provisions remain developed Western European and North American states targeting developing 
states. And authorities in the developed world acknowledge that the system works mostly on their behalf, with few worries about challenges from the developing world. The USTR notes for instance, "Because of the safeguards in US agreements and because of the high standards of our legal system, foreign investors rarely pursue arbitration against the United States and have never been successful when they have done so" (USTR, 2015).

The evolution of jurisprudence on enforcement of international arbitration awards under the New York and Washington conventions could prevent states from ducking their obligations and avoiding claims for compensation. They can also expose sub-national units like states or provinces to court sanction and even expropriation of property internationally if they did not enforce ISDS or declined to pay penalties appropriately. Evolving jurisprudence in the US and other jurisdictions may permit claimants aggrieved at national or sub-national policies to sue in foreign courts and have assets of those states or provinces seized as compensation (Van Harten \& Loughlin, 2006).

Supporters of such provisions suggest they protect investors and clarify investment rules and ensure that investors can obtain redress for laws or regulations which erode profit potential. UNCTAD outlines the core goals succinctly: "IIAs may offer an avenue for the resolution of investor-State disputes that allow significant disagreements to be overcome and the investment relationship to survive. Equally, where the disagreement is fundamental and the underlying relationship is at an end, the system offered by an IIA might help to ensure that an adequate remedy is offered to the aggrieved party and that the investment relationship can be unwound with a degree of security and equity, so that the legitimate expectations of both parties can, to some extent, be preserved" (UNCTAD, 2003, p. 8). Many business sectors and associations (Carroll and Sapinskis' transnational networks of multi-national firms and lobbying associations) have come out soundly in favour of such measures. Clarity in rules is seen to promote efficient investment flows. Consistency is required through the inclusion of these measures in agreements, even where states have developed systems of law whereby domestic protections and legal recourse exist for investors who are unduly deprived of profit or assets.

Given the variation between established and new member states, some of which are still fleshing out the rule of law, European Union members have been key exponents of such disputes resolution measures. After the Lisbon treaty transferred competence, investment treaties are now dealt with by the European Commission (Bungenberg, 2010; Chaise, 2012). This has created complications with leading states like Germany and France and Commission actors over whether to include such measures in agreements with Canada and the US. Those two North American nations included ISDS measures in Chapter 11 of NAFTA.

Critics portray the ISDS mechanism as a threat to democracy and public policy, with a chilling effect on social and environmental programs and regulations. It is also considered as unnecessary between developed states like the EU and the US, in view of the strength of investment protections in their national legal systems. These views are articulated by most trade unions, a large number of NGOs, consumer organisations and others who responded in the EU consultations on ISDS in TTIP and the US consultations on the updated model BIT. Many of these groups express specific concerns about governments being sued by corporations for high amounts of money which in their view create a "chilling effect" on the right to regulate. Documents from trade unions and social NGOS express a generic mistrust of the independence and impartiality of arbitrators and a concern that ISDS may allow investors to circumvent domestic courts, laws or regulations. A number of trade unions and NGOs consider that the changes in the US model BIT and more recent EU deals to discourage frivolous cases and increase transparency and accountability are insufficient to address their concerns.

Cases are not inevitably decided in favour of investor, with states prevailing in many instances, though investor wins and settlements occur in a majority of cases (Figure 5). Costly settlements as well as successful claims can, critics fear, become constraints on state decision-making. While not all decisions favour claimants, there has been an escalation in both the number and size of clams and more cases have included sometimes substantial penalties. The true extent of the impact is hard to gauge. The EU trade directorate notes that a "complete overview is difficult because information on the amounts claimed and awarded is not always disclosed, even in cases that are public" (EU Commission, 2015 , p. 8) a lack of transparency which is problematic for analysts.

The awards fall short of initial claims overall (Table 2 ). Depending on the state involved the amounts still can be quite crippling on top of the costs of managing the complex system and hiring necessary expertise, which can run into multiple millions of dollars; one Eastern European participant at a recent conference said such cases consumed nearly half of his small country's justice ministry budget.

However, high profile cases (Table 3 ) have provided fuel for opponents. These critics complain of the imposition of restrictions on state decision-making which runs against the democratic accountability of government. They also note that the closed non-transparent system, with arbitrations by for-profit firms which leads to frivolous lawsuits to secure payouts for investors and their specialized legal teams. Environmental regulations are often a key concern, with Canadian provinces like Quebec and New Brunswick facing challenges to their limits on fracking and Nova Scotia facing a suit under NAFTA 


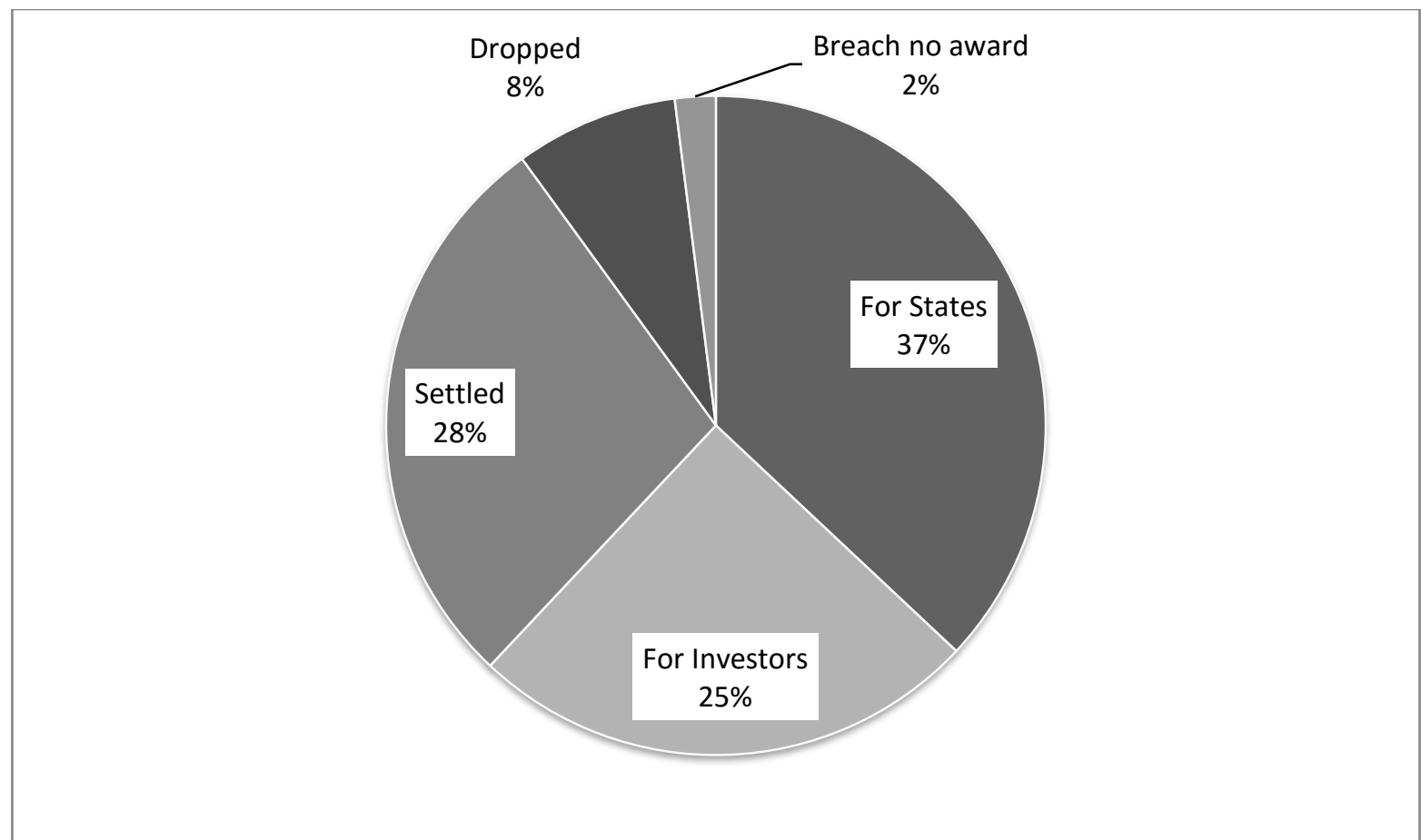

Figure 5. Arbitration results to end 2014. Source: http://investmentpolicyhub.unctad.org/ISDS

Table 2. Total claims, awards and settlements in \$1 million. Source: http://investmentpolicyhub.unctad.org/ISDS/ FilterByAmounts

\begin{tabular}{llll}
\hline Amounts $\$ \mathbf{1 m}$ & $\begin{array}{l}\text { \# of times Sought by } \\
\text { Claimants }\end{array}$ & \# of Tribunal Awards & $\begin{array}{l}\text { \# of times reached in } \\
\text { Settlements }\end{array}$ \\
\hline$<\$ 1 \mathrm{~m}$ & 5 & 10 & 0 \\
$\$ 1-9.9 m$ & 37 & 33 & 2 \\
$\$ 10-99.9 m$ & 148 & 42 & 15 \\
$\$ 100-499.9 m$ & 156 & 19 & 9 \\
$\$ 500-999.9 m$ & 50 & 3 & 5 \\
$>\$ 1000 m$ & 80 & 5 & 2 \\
\hline
\end{tabular}

Table 3. Contentious ISDS cases. Source: Adapted from Van Harten, Porterfield and Gallagher (2015)

\begin{tabular}{ll}
\hline Legislative Fields & Example Cases \\
\hline Health Care & Eli Lilly vs Canada (drug prices) \\
& Phillip Morris vs Uruguay (tobacco) \\
\hline Environment & Chevron vs Ecuador (Amazon protection) \\
& Vattenfall vs Germany (nuclear energy ban) \\
& Renco vs Peru (mining permits and wastes) \\
& Lone Pine Resources vs Canada (fracking ban) \\
& Windstream Energy vs Canada (green energy) \\
\hline Labour Rights & Veolia vs Egypt (minimum wage) \\
& Laval vs Sweden (contract labour standards) \\
& Piero Foresti vs South Africa (affirmative action) \\
\hline Financial Institutions & Abalclat vs Argentine Republic (debt relief) \\
& Saluka vs Czech Republic (too big to fail) \\
\hline Utilities & Vivendi vs. Argentina (water/wastewater pricing) \\
& LG\&E International. v. Argentina (energy pricing) \\
\hline
\end{tabular}

for rejecting permission for a quarry. European states have also begun to face such challenges, with Sweden fighting the Laval case respecting provision of contract workers at below national labour standards and Germany challenged in the Vattenfall case for its post-Fukushima move away from nuclear power. For Europe, being on the receiving end of such actions as could happen more frequently with TTIP is novel, since EU member states were 
the principle architects of and users of ISDS over the years in a plethora of bilateral investment deals.

There is some evidence that "the high costs of ISDS or the threat of such costs can have a dissuasive effect on states and that investors can use the spectre of highcost ISDS litigation to bring a recalcitrant state to the negotiating table for purposes of achieving a settlement of the dispute" though similar disincentives can also force investors to abandon or settle a claim (OECD, 2012, p. 9). According to UNCTAD, with "its expansive, and sometimes contradictory, interpretations, the arbitral process has created a new learning environment....Issues of transparency, predictability and policy space have come to the forefront of the debate as has the objective of ensuring coherence between IIAs and other areas of public policy, including policies addressing global challenges, such as the protection of the environment (climate change) and public health and safety" (UNCTAD, 2014, p. 4).

\section{Implications of ISDS Systems for Global Governance}

Investment treaties-coupled with equally powerful agreements on trade in goods and services, intellectual property, regulatory convergence etc.-have transformed the nature of international governance and its impact on the state in a globalized era. "To an unusual extent trading states have delegated to impartial third parties the authority to review and issue binding rulings on alleged treaty violations, at times based on complaints filed by nonstate or supranational actors" (Smith, 2000, p. 137). Investment disputes provide an important instance of this state delegation. McBride remarked on how Chapter 11 in NAFTA illustrated this process whereby "states have sanctioned a significant transfer of authority from public to private control. Essentially, a portion of national sovereignty is surrendered, not just to international entities, but to private ones" (McBride, 2006, p. 755).

Defenders of the system correctly note that under democratic constitutional principles, states have rights to enter into binding agreements to protect the rights of private partners, so nothing about the measures is a departure from constitutional principles (despite critical references to the MAI or ISDS system as a "coup d'etat"). Nevertheless, it does reflect a fundamental choice to empower some rights holders, including foreign investors, above others, and thereby to either constrain policy or impose costs on states which decide not to respect investor rights or to pursue policies (regulations, nationalizations, local preferences) which challenge, limit or remove those rights. Additionally, while the systems cannot force countries to adjust laws, they can make jurisdictions wary, change policies by anticipation or adjustment if costs are considered too high (developing countries or have not provinces or states for instance may have to think twice about absorbing such costs). And the privatized arbitration system, run by international lawyers who also work for claimant corporations or investors in other roles, has also been questioned.

As Figure 6 indicates, there has been a steady uptake in the number of claims by investors and the resolution of these claims. To some extent this can be accounted for by the increase in FDI and the increase in the number of BITs. This represents however, an increased willingness to defer to international institutions and legal norms at the expense of local particularism and democratic input. As such, it is a powerful new form of transnational governance regime which increasingly affects many nations. As the Stockholm Chamber of Commerce suggests "The increasing number of ISDS cases may be described as an increase of trust and reliance on international law in general, and to international arbitration specifically, both by investors and States" (SCC 2015).

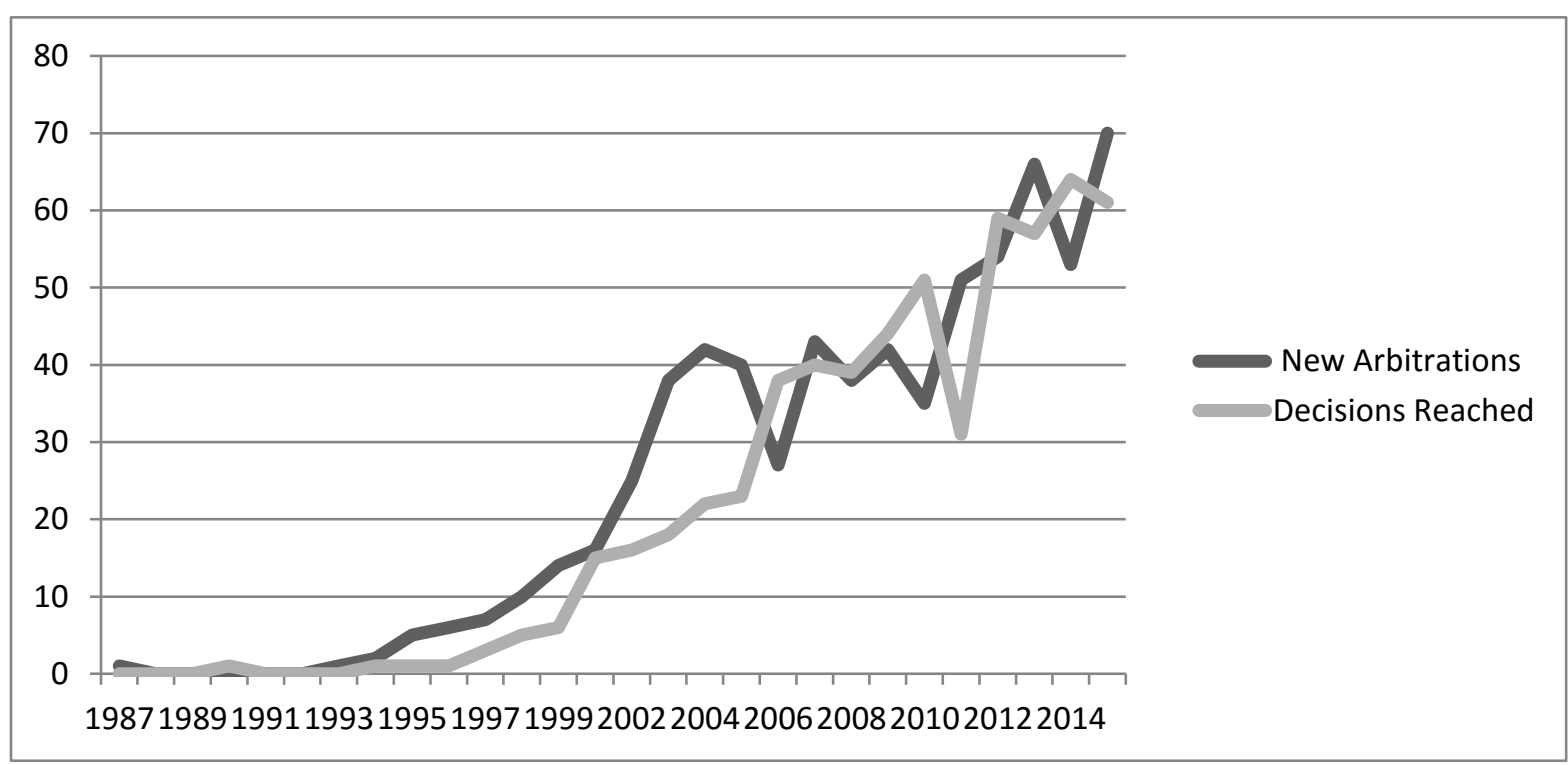

Figure 6. Increased ISDS activity. Source: http://investmentpolicyhub.unctad.org/ISDS/FilterByYear 
There has been recognition for several years among legal scholars of the profound changes implied by this transnational system, which Foster (2015) terms the emergence of "internationalized public law". In particular, the notion of sovereignty as traditionally associated with state authority is being altered. Instead of sovereign-sovereign relations, these deals substitute individual-sovereign relations in ways which empower private parties, especially investors. "The BIT...creates a public international law instrument that endows the individual foreign investor with direct international standing" (Kaushal, 2009, pp. 498-499). And the awards, made by private sector arbiters (often law firms that do work in other circumstances for the plaintiff corporations) are transnationally enforceable under UN conventions on enforcement of arbitral awards. While in the early years, the provisions were used infrequently, the number of known disputes cases has accelerated from 19 in 1997, to 300 by 2007, and some 514 by the end of 2012. Hence what was once a rarity has become much more common. And the spread of claims across a wide range of policy areas (Table 4) has significant implications for government regulatory and policy autonomy and accountability to the electorate.

Bilateral and regional ISDS provisions have broken down the boundaries between international and national and arguably enhanced the rights of private actors at the expense of public governance. For critics, the transnational plutocracy of investors have obtained rights superior to domestic investors and citizens. There is increased pluralism among capital exporting states, though the dominance of the US, Europe, Japan and emergent states remains significant; developing states remain mostly takers of such arrangements despite evidence that the flow of investment is not substantially augmented by such deals-many states are bargaining away sovereignty for very limited returns.

Supporters deny that ISDS provisions can be used to challenge government policies, declaring that "critics exaggerate the notion that investors 'sue to overturn regulations'; BITs explicitly limit awards to monetary damages" (Miller \& Hicks, 2015, p. v). Yet the scale of some awards relative to the size of smaller governments' budgets makes them punitive to the point that regulations could be altered or perhaps not introduced in the first place. Some companies have been accused of buying firms in jurisdictions in order to use the provisions of investment treaties, and high legal fees encourage expensive drawn out deliberations (The Economist, 2014). Investors certainly understand the potential for dissuasion beyond the actual punitive level of awards as the threat of arbitration can pressure states to fulfil treaty obligations on FDI as states try to avoid even the prospect of a claim to preserve their reputation as a safe haven for investors (Olivet \& Eberhardt, 2012).

\section{Emerging Resistance and Potential Reform}

As Held suggests the global governance complex in this field contains non-governmental actors other than corporate or plutocratic ones such as unions, social and human rights groups which have exerted pressure on states to alter or opt out of the investor arbitration system. Fabry and Garbasso (2015) note that the increase in ISDS measures and claims have generated fears for their impact on sovereignty which has led some states to withdraw from existing agreements or forgo proposed new pacts. The political and economic costs appear in some cases to outweigh the perceived benefits of participation in ISDS provisions. Several states which historically have supported ISDS measures in their dealings with weaker states have emerged as critics. Significant emerging states, notably India and South Africa, have opted out of ISDS measures in bilateral deals and contributed to the defeat of the MAI. Australia's centreleft Gillard government also rejected inclusion of additional ISDS provisions from 2011 (Tienhaara \& Ranald, 2011) though this has since been reversed by the more conservative Liberal-National regime which signed the TPP.

Most notably, European actors have suggested that inclusion of ISDS in CETA and TTIP might not prove viable. Having pioneered the technique in dealings with developing states, European countries now are concerned about potential losses from American firms use of the investor-state disputes process and attendant penalties. European discontent has induced a change in the EU negotiating position on TTIP and a renegotiation of portions of CETA to adjust the ISDS provisions; some of these changes appear to move beyond the cosmetic to substantive proposals for a more autonomous bilateral (and eventually multinational) investment court, freed

Table 4. Leading claims by economic sector. Source: http://investmentpolicyhub.unctad.org/ISDS/FilterByEconomicSector

\begin{tabular}{lll}
\hline Primary resources & Secondary manufacturing & Tertiary services \\
\hline Petroleum and gas (57) & Food Products (25) & Electric, Gas, AC (139) \\
Metal Mining (32) & Chemicals (14) & Financial /Insurance (64) \\
Other mining/quarries (14) & Base Metals (12) & Construction/engineering (63) \\
Crop and Animal (14) & Nonmetal minerals (12) & Telecommunications/IT (47) \\
Forestry/logging (8) & Pharmaceuticals (8) & Water supply/waste (45) \\
Coal mining (6) & Beverages (4) & Transport/Storage (39) \\
Mining Support (4) & Tobacco (4) & Wholesale/Retail (16) \\
Fisheries/aquaculture (4) & Textiles (4) & Accommodation/Food (9) \\
\hline
\end{tabular}


from the corporate dominance of existing arbitration arrangements. How seriously this is intended and whether it becomes a "red line" for ISDS negotiations going forward remains to be seen (Van Harten, 2015).

Concern is also evident in the United States, despite its insistence on its bilateral investment treaty model in all negotiations. Alarmed by growing arbitral boldness and breadth under measures like NAFTA Chapter 11, the USTR tweaked investment treaties to decrease the constraint on policy options. They "have stepped into line with the developing countries that have sought greater tribunal deference to sovereign regulatory decisions" (Kaushal, 2009, p. 495). This has affected the US Model BIT from 2004 onwards as new deals included guarantees for greater precision on covered investments and standards of treatment, more transparency, third party intervention and guarantees for financial, labour, environment health and safety regulations. But this did not remove the private arbitration system, and the Americans included similar disputes resolution measures in new mega treaties like TPP and TTIP. Critics like Senator Elizabeth Warren warn that ISDS provisions in such deals could tilt the political and economic playing field even further towards large corporate players (Jacobs, 2015). Even some prominent promoters of freer trade have come to see ISDS as an impediment to some transnational agreements, notably the TTIP with Europe (Ikenson, 2014).

Simple measures like enshrining requirements for transparency and third party interventions have been suggested to address the biases and secrecy of processes like those under NAFTA Chapter 11 (Van Duzer, 2007). The European Commission introduced such changes to its ISDS treaties. These would ensure that public interest legislation and regulations should take precedence, and "guidance" to the arbitrators to ensure that companies are not compensated "just because their profits have been reduced through the effects of regulations enacted for a public policy objective". The original CETA draft included a clearer definition of "fair and equitable treatment" to prevent "manifest arbitrariness, abusive treatment (coercion, duress or harassment), or failure to respect the fundamental principles of due process". It also included measures to dissuade frivolous claims, including a stipulation that the losing party should bear all litigation costs; measures to promote transparency of international tribunals including public access to documents; a code of conduct for arbitrators; and safeguards to reduce erroneous rulings including opportunities for the home country of the states to make interventions in the process (EU Commission, 2013).

Under domestic pressure from critics who worried about the ISDS provisions in TTIP, the EU held a consultative process and added amendments, including creation of a permanent bilateral investment court with judges appointed by the two parties with neutral appointees from a third party (EU Commission, 2015). The
Canadian Liberal government agreed to CETA amendments along these lines, but the US has balked at anything outside its model BIT and insists on the use of private arbitrators as in NAFTA and the recently drafted TPP. After an exhaustive review of the US "model bilateral investment treaty" with numerous inputs from critics and supporters, the 2012 model BIT only contained slight revisions of the 2004 version. Most importantly, the disputes resolution model was left intact, and this has continued through subsequent negotiations including the TPP (Di Rosa, 2012). Policy analysts suggest the EU proposal is not really a court and does not differ from the arbitration model which is the source of the constraint on sovereignty and democratic governance (Butler, 2016).

UNCTAD has lead efforts to revise ISDS provisions to address many of the concerns raised by critics, including increasing transparency and guaranteeing a legitimate right to regulate. Reforms would promote alternative disputes resolution, provide legal assistance to developing states, limit those investors and claims subject to arbitration, introduce appeals procedures and third party participation and eventually create a transnational investment court system to address concerns respecting the closed and costly nature of the private arbitration system (UNCTAD 2013). Recent agreements have featured adjustments to assuage concerns about impositions on sovereignty; these include "a wide range of exceptions, interpretations and detailed provisions designed to protect the exercise of authority by contracting governments, with the aim of protecting public policies regulating commercial transactions, consumer protection, environmental and health standards and the protection of human rights" (de Mestral, 2015, p. 2).

But critics remain unconvinced, suggesting that the right of investors to sue states for losses of investment values could have a detrimental effect on environment, worker rights, and regulatory flexibility. They oppose the creation of arbitral councils which would sit in judgement above and apart from governments. Legal analysts suggest that the phrasing in the CETA texts for instance, which guarantees a right to regulate subject to provisions of the agreement, does not ensure that a disputes process won't be used to overturn regulations enacted by a democratically elected government.

"The legal analysis of this approach is extremely clear and simple: it does nothing to establish or enhance a right to regulate. Rather, it does the exact opposite: it makes it clear that the right to regulate is fully subject to the Agreement. All exercises of the right to regulate, at both the federal and provincial levels, must conform to the agreement. Contrary to what is often implied by referring to a 'right to regulate' provision, this approach in fact prioritizes conformity with treaty obligations over the right to regulate." (Bernasconi-Osterwalderm \& Mann, 2014, p. 2) 
For critics, this makes clear that the treaty obligations would make a "right to regulate" meaningless. Treaty provisions would take precedence over regulatory independence at the national as well as subnational levels, with ongoing implications for the balance of powers between levels of government. As to the final proposed compromise, social and union groups unequivocally see it as inadequate: "this cosmetic exercise will resolve none of the fundamental concerns about granting special privileges for foreign investors, undermining national laws and bypassing domestic courts" (EPSU, 2015).

Furthermore, states have not made strong use of provisions to influence the system and certainly exit from such treaties may be prohibitively costly for most states; and treaty provisions in many cases allow for extended application for a decade or more past termination (Gordon \& Pohl, 2015). Hence the system stays in place across changes in governments and as with Australia (Thurbon, 2015, p. 466) withdrawal from ISDS provisions isn't sustained over time. While more claims are settled in favour of states, when taken together with settlements, investors may well succeed in more instances, though the secrecy respecting awards and settlements makes a clear determination impossible.

Investors certainly acknowledge that the new transnational rules can thwart state efforts to escape penalties. Investors speak positively about using arbitration not only to redress losses but to provide another means to bolster investment value and offset risks. Legal observers in the arbitration community certainly regard the arbitration regime as effective, especially as the Washington and New York Convention arbitration rules are now enforced by courts in investment exporting states. This system ensures that countries, despite efforts, cannot escape their obligation to pay awarded damages (Olivet \& Eberhardt, 2012). While supporters are correct that ISDS by itself cannot impose policy requirements on states, some concede that there will be real constraints on policy choices. "It is true to the extent that ISDS clauses might indirectly influence governments when considering law changes that might affect foreign investors. Governments will need to consider the equitable treatment of investors from countries with whom they have ISDS arrangements-essentially ISDS points out the potential financial consequences of introducing laws that are clearly discriminatory and unfair" (Export New Zealand, 2015).

\section{Conclusion: Plutocratic Transnational Governance}

Hence the investor state disputes settlement system has become something more than an external constraint on the competition state. It has morphed instead into a forceful transnational system, a global governance complex implemented at the behest of international investors who are its primary beneficiaries. While states have the prerogative to sign binding international commitments in such areas, addition of investor states arbitration mechanisms permits private parties to challenge a wide range of domestic policy decisions in ways which may challenge sovereignty and democratic accountability. David Schneiderman (2008) suggests the ISDS regime has produced a form of transnational constitutionalism which limits states and diminishes the scope for democratic policy making. It has at least altered the environment for policy making as states anticipate and adjust to avoid costly penalties. Proposals for reform may potentially correct some of the imbalances if they increase transparency, limit frivolous claims, and seriously protect a right to regulate. So far analysts are divided on the potential. And the US unwillingness to move significantly from its model BIT towards the EU proposal for a transnational investment court to replace ad hoc private arbitration leaves some doubt. Certainly the provisions in the recently concluded TPP seem primarily similar to those in the US model BIT, in NAFTA and previous US treaties which are restrictive of state policy.

The system is also only one of a range of transnational innovations undertaken over the past 30 plus years, including those in intellectual property protection, regulation harmonization, trade in goods and services, etc. which have created a multifaceted transnational system, a web from which states can scarcely extricate themselves. The investment arbitration system reflects the emergence of a multifaceted "global governance complex" driven primarily by the interests of a transnational pluralistic plutocracy of global firms and lobbyists, (countered only partially by transnational civil society actors), which renders liberal democratic accountability increasingly elusive or even chimerical and augments the power of the wealthy in domestic politics. As Stephen Clarkson points out, for small states at least, this new global governance paradigm via investment and other regimes creates a democratic deficit as governments lose the ability to respond to citizens' wishes (Clarkson, 2003, pp. 152, 162). Liberal democracies may become "pluralistic plutocracies" where electoral competition becomes less meaningful in economic and related realms - a form of "post-democracy" which helps explain the narrowing of meaningful political choice in many though not all policy areas.

This essay has focussed on the ISDS system, which may impose new limits on states. Other agreements in areas like intellectual property require states to reign in citizens also on behalf of the transnational plutocratic interests which warrant further analysis in future studies. This is an example of the "paradox of the competition state". Far from eroding states, many measures on security, intellectual property and other new economy themes force states to coerce their population to conform to transnational norms, reduce competition and choice for consumers, and restrain individual liberties via intrusive, punitive enforcement mechanisms. The 
implications for theories of the democratic state remain to be investigated across the plethora of multinational, regional, and bilateral investment, trade and services agreements which are transforming global governance.

\section{Conflict of Interests}

The author declares no conflict of interests.

\section{References}

Åslund, A. (2013). The world needs a multilateral investment agreement. Peterson Institute for International Economics Policy Brief (PB 13-01). Washington, DC: Peterson Institute.

Bernasconi-Osterwalderm, N., \& Mann, H. (2014). A response to the European Commission's December 2013 document "Investment provisions in the EU-Canada Free Trade Agreement (CETA)". Winnipeg, Canada: The International Institute for Sustainable Development. Retrieved from http://www.iisd.org/pdf/20 14/reponse_eu_ceta.pdf

Bungenberg, M. (2010). Going global? The EU common commercial policy after Lisbon. In C. Hermann \& J. P. Terhechte (Eds.), European yearbook of international economic law (pp. 123-151). Berlin: Springer.

Butler, N. (2016). The EU investment court proposal in TTIP: ISDS 2.0. Policy Briefing. Manchester, UK: University of Manchester. Retrieved from http://documents.manchester.ac.uk/display.aspx?DoclD $=2867$

Carroll, W. K., \& Sapinski, J. P. (2010). The global corporate elite and the transnational policy-planning network, 1996-2006. A structural analysis. International Sociology, 25(4), 501-538.

Cerny, P. (1997). Paradoxes of the competition state: the dynamics of political globalization. Government and Opposition, 32(2), 251-274.

Cerny, P., Menz, G., \& Soederberg, S. (2005). Different roads to globalization: Neoliberalism, the competition state, and politics in a more open world. In P. Cerny, G. Menz and S. Soederberg (Eds.), Internalizing Globalization (pp. 1-30). New York, NY: Palgrave Macmillan.

Chaisse, J. (2012). Promises and pitfalls of the European Union policy on foreign investment-How will the new EU competence on FDI affect the emerging global regime? Journal of International Economic Law, 15(1), 51-84.

Clarkson, S. (2003). Locked in? Canada's external constitution under global trade governance. American Review of Canadian Studies, 33(2), 145-172.

Crouch, C. (2000). Coping with post-democracy. London: Fabian Society.

de Mestral, A. (2015). Investor state arbitration between developed countries. Investor-state Arbitration Series 1. Waterloo: Centre for International Governance Innovation.
Di Rosa, P. (2012). The new 2012 U.S. model BIT: Staying the course. Kluwer Arbitration Blog. Retrieved from http://kluwerarbitrationblog.com/2012/06/01/thenew-2012-u-s-model-bit-staying-the-course

European Commission (DG Trade). (2013). Fact sheet: Investment protection and investor-to-state dispute settlement in EU agreements. Retrieved from http:// trade.ec.europa.eu/doclib/docs/2013/november/ tradoc_151916.pdf

European Commission (DG Trade). (2015). Commission draft text TTIP-Investment transatlantic trade and investment partnership trade in services, investment and e-commerce chapter II-Investment. Retrieved from http://trade.ec.europa.eu/doclib/docs/2015/se ptember/tradoc_153807.pdf

European Federation of Public Service Unions (EPSU) (2015). EPSU update on the Comprehensive Economic and Trade Agreement (CETA), Transatlantic Trade and Investment Partnership (TTIP), the Trade in Services Agreement (TiSA). Retrieved from http://www.epsu. org/sites/default/files/article/files/Trade_Update_Se ptember_2015.pdf

Export New Zealand. (2015). ISDS and sovereignty. Wellington: Export New Zealand. Retrieved from http:// www.businessnz.org.nz/_data/assets/pdf_file/0009 /109179/ISDS-and-Sovereignty.pdf

Fabry, E., \& Garbasso, G. (2015). "ISDS" in the TTIP: The devil is in the details. (Policy Paper No. 122). Paris: Jacques Delors Institute. Retrieved from http:// www.institutdelors.eu/media/ttipisds-fabrygarbasso -nejdi-jan15.pdf?pdf=ok

Foster, C. (2015). A new stratosphere? Investment treaty arbitration as "internationalized" public law. The International and Comparative Law Quarterly, 64(2), 461-485.

Gathii, J. T. (2011). The neoliberal turn in regional trade agreements. Washington Law Review, 86(3), 42-474.

Gordon, K., \& Pohl, J. (2015). Investment treaties over time-Treaty practice and interpretation in a changing world. OECD (Working Papers on International Investment 2014/2). Paris: OECD. Retrieved from http://www.oecd.org/investment/investment-policy/WP-2015-02.pdf

Hall, S. (2011). Educational ties, social capital and the translocal (re)production of MBA alumni networks. Global Networks, 11(1), 118-138.

Held, D. (2004). Democratic accountability and political effectiveness from a cosmopolitan perspective. Government and Opposition, 39(2), 364-391.

Held, D. (2010). Cosmopolitanism: Ideals and realities. Cambridge, UK: Polity.

Ikenson, D. J. (2014). A compromise to advance the trade agenda: Purge negotiations of investor-state dispute settlement. Washington: CATO Institute.

Jacobs, B. L. (2015). A perplexing paradox: "De-statification" of "investor-state" dispute settlement? Emory International Law Review, 30(1), 17-49. Retrieved 
from http://law.emory.edu/eilr/content/volume-30/ issue-1/articles/perplexing-paradox-de-statificationinvestor-state-dispute.html

Kaushal, A. (2009). Revisiting history: How the past matters for the present backlash against the foreign investment regime. Harvard International Law Journal, 50(2), 491-534.

McBride, S. (2006). Reconfiguring sovereignty: NAFTA chapter 11 dispute settlement procedures and the issue of public-private authority. Canadian Journal of Political Science, 39(4), 755-775.

Miller, S. \& Hicks, G. (2015). Investor-state dispute settlement: A reality check. (Report of the CSIS Scholl Chair in International Business Centre for Strategic and International Studies). New York: Roman and Littlefield. Retrieved from http://csis.org/files/publication/150 116_Miller_InvestorStateDispute_Web.pdf

Olivet, C., \& Eberhardt, P. (2012). Profiting from injustice: How law firms, arbitrators and financiers are fuelling an investment arbitration boom. Transnational Institute. Retrieved from https://www.tni.org/en/briefing/profiting-injustice

Organization for Economic Cooperation and Development (OECD). (2012). Government perspectives on investor-state dispute settlement: A progress report. Freedom of investment roundtable. Retrieved from www.oecd.org/daf/inv/investment-policy/ISDSprogressreport.pdf

Peterson L. E. (2004). Bilateral investment treaties and development policy-making. Winnipeg, Canada: International Institute for Sustainable Development. Retrieved from http://www.iisd.org/pdf/2004/trade _bits.pdf

Schneiderman, D. (2008). Constitutionalizing economic globalization: Investment rules and democracy's promise. Cambridge, UK: Cambridge University Press.

Smith, J. M. (2000). The politics of dispute settlement design: Explaining legalism in regional trade pacts. International Organization, 54(1), 137-180.

Stockholm Chamber of Commerce (SCC). (2015). What caused the rise of ISDS claims? ISDS Blog. Retrieved from: http://isdsblog.com/2015/01/30/what-causedthe-rise-of-isds-claims/\#sthash.w5LpwGsL.dpuf

Stumberg, R. (1998). Sovereignty by subtraction: The multilateral agreement on investment. Cornell International Law Journal, 31(3), 492-598.

The Economist (2014). The arbitration game. The Economist Retrieved from http://www.economist.com/ne ws/finance-and-economics/21623756-governmentsare-souring-treaties-protect-foreign-investors-arbitration

Thurbon, E. (2015). 10 years after the Australia-US free trade agreement: Where to for Australia's trade policy? Australian Journal of International Affairs, 69(5), 463-467.

Tienhaara, K. (2011). Regulatory chill and the threat of arbitration: A view from political science. In C. Brown \&
K. Miles (Eds.), Evolution in investment treaty law and arbitration. Cambridge, UK: Cambridge University Press.

Tienhaara, K., \& Ranald, P. (2011). Australia's rejection of investor-state dispute settlement: Four potential contributing factors. Investment Treaty News. Retrieved from http://www.iisd.org/itn/2011/07/12/australiasrejection-of-investor-state-dispute-settlement-fourpotential-contributing-factors/

United Nations Conference on Trade and Development (UNCTAD). (2000). Bilateral investment treaties 19591999. Geneva: UNCTAD. Retrieved from http://un ctad.org/en/Docs/poiteiiad2.en.pdf

United Nations Conference on Trade and Development. (2006). The entry into force of bilateral investment treaties (BITS). Geneva: UNCTAD. Retrieved from http://unctad.org/en/Docs/webiteiia20069_en.pdf

United Nations Conference on Trade and Development. (2013). Reform of investor-state dispute settlement: In search of a roadmap. Geneva: UNCTAD. Retrieved from http://unctad.org/en/PublicationsLibrary/webdiaepcb2013d4_en.pdf

United Nations Conference on Trade and Development. (2014). Investor-state dispute settlement. Geneva: UNCTAD. Retrieved from http://unctad.org/en/PublicationsLibrary/diaeia2013d2_en.pdf

United Nations Conference on Trade and Development. (2015). Investment-states disputes settlement: a review of developments in 2014. Geneva: UNCTAD Retrieved from http://investmentpolicyhub.unctad.org/ Upload/Documents/UNCTAD_WEB_DIAE_PCB_2015 _\%202\%20IIA\%2OISSUES\%2ONOTES\%2013MAY\%20. pdf

United States Trade Representative (USTR). (2015). Investor-state dispute settlement (ISDS). Washington, DC: USTR. Retrieved from https://ustr.gov/about-us/policy-offices/press-office/fact-sheets/2015/march/investor-state-dispute-settlement-isds

Van Duzer, J. A. (2007). Enhancing the procedural legitimacy of investor-state arbitration through transparency and amicus curiae participation. McGill Law Journal, 52(4), 681-723.

Van Harten, G. (2015). A parade of reforms: The European Commission's latest proposal for ISDS. Osgoode Legal Studies Research Paper (No. 21/2015). Retrieved from SSRN http://dx.doi.org/10.2139/ssrn.2603077

Van Harten, G., \& Loughlin, M. (2006). Investment treaty arbitration as a species of global administrative law. European Journal of International Law, 17(1), 121-150.

Van Harten, G., Porterfield, M., \&. Gallagher, K. P. (2015). Investment provisions in trade and investment treaties: The need for reform. Global Economic Governance Initiative Policy Brief. Retrieved from http:// www.bu.edu/pardeeschool/files/2014/12/InvestorState-Disputes-Policy-Brief.pdf

Vandevelde, K. J. (2005). A brief history of international investment agreements. Journal of International Law 
and Policy, 12(1), 157-194.

Verhoosel, G. (2003). The use of investor-state arbitration under bilateral investment treaties to seek relief for breaches of WTO law. Journal of International Economic Law, 6(2), 493-506.

\section{About the Author}

Robert Finbow, Professor of Political Science at Dalhousie University, received his doctorate from the London School of Economics. A recipient of SSHRC and Fulbright fellowships, he has published on trade, labour and environmental policies in NAFTA and the EU, comparative political cultures, social policy in North America and regionalism in Atlantic Canada. His recent research has been on European Union social and trade policy, and the Canada-European Economic and Trade Agreement, especially the implications for social policy and investment. 